\title{
Uterine Corpus Carcinoma Clinical TNM
} Finding v7

National Cancer Institute

\section{Source}

National Cancer Institute. Uterine Corpus Carcinoma Clinical TNM Finding v7. NCI

Thesaurus. Code C89575.

A clinical finding about one or more characteristics of uterine corpus carcinoma, following the rules of the TNM AJCC V7 classification system. TNM clinical findings are based on information obtained prior to the first definitive treatment through physical examination, diagnostic imaging, biopsy and laboratory testing. 